legitimering, buddhisme og hinduisme i Indien, de tamilske tigre etc. For ikke at nævne kapitler om nutidig islamistisk legitimering af terror. Det skal også nævnes, at bogen kunne have brugt en strammere redigering, da nogle kapitler er uforholdsmæssigt lange, og da der er en række gentagelser kapitlerne imellem.

Ingen af disse kritikpunkter ændrer dog ved, at denne bog udfylder et hul i den danske debat om krig - ført af og imod os - der tilsyneladende med hastige skridt genopliver religionens forestillinger om krig som en kamp mellem mørkets og lysets kræfter. I den situation er denne bog en god introduktion til, hvordan religionen altid har tilbudt sig, når folk skulle slås ihjel.

Mikkel Thorup

\section{Anderledes idéhistorie}

Carsten og Malene Fenger-Grondabl: Sigojnere - 1000 år på kanten af Europa. Aarbus Universitetsforlag, 2006, 408 sider, kr. 348,-

Denne bogs tema synes ved første øjekast måske ikke udpræget idéhistorisk, men man skal ikke lede længe efter den idé, der belyses historisk. Som titlen antyder, er værkets hovedpersoner en af Europas mest myteomspundne minoriteter, romafolket eller sigøjnerne, betegnelsen som stadig er den, der umiddelbart vækker genkendelse hos flest. Forfatterne har besøgt romabefolkningen i 10 forskellige lande og lader dem i høj grad selv fortælle deres historie. Bogen indeholder et væld af vedkommende referencer til rapporter både fra lokale, regionale og internationale organisationer samt et sjældent indblik i, hvordan politi og sociale institutioner tackler diskrimination og spændinger mellem befolkningsgrupper med et realistisk udgangspunkt. Carsten og Malene Fenger-Grøndahl er uddannet henholdsvis idéhistoriker og journalist, og de har tidligere skrevet blandt andet bogen Flygtningenes Danmarkshistorie 1954-2004. Kombinationen af de to forfatteres forskelligartede faglighed giver deres bøger en spændende dybde formuleret $i$ et lettilgængeligt sprog.

Siggjnere - 1000 àr på kanten af Europa er en rejsebog, der beskriver mennesker, landskaber, bygninger, stemninger, lyde og lugte, hvor end forfatterne kommer frem. Titlen afspejler kernen i romafolkets historie og de vilkår, som romaerne lever under mange steder i Europa. Den gennemgående idé, der har præget (og stadig præger) romaernes tilværelse, er forestillingen om sigøjneren - den omrejsende, mystiske kvinde med flagrende skørter og patent på fremtiden i sin krystalkugle; de fattige børn, der tigger; mænd med overskæg og hat, en sjælden dovenskab i kroppen og en naturlig tilskyndelse til at stjxle med arme og ben. Kort sagt mennesker, der ikke er ligeværdige i de europæiske samfund grundet de- 
res 'naturlige dispositioner'. Forfatterne viser, at denne forestilling, der dybest set er ren racisme, er en af de bedst institutionaliserede stereotyper i Europa. Idéens historie fortjener en så grundig behandling, som den får i værket, netop fordi det er en idé om en meget stor gruppe mennesker, der ikke selv har nogen indflydelse på ikke-romaers opfattelse af deres etnisk-kulturelle identitet. Man sidder unægtelig tilbage med en dårlig smag i munden, f.eks. når man læser om det folkemord, der blev begået mod romaerne under Anden Verdenskrig, som siden blev nægtet den moralske oprejsning, de havde krav på - og som alle uden at blinke tilkendte jøderne. Selv blandt de udstødte er romaerne udstødt.

Historien om romaerne i Europa er Europas historie set med den radikalt marginaliseredes øjne. Bogen er uhyre interessant for sin praktiske tilgang til en idéhistorisk problemstilling - eller i hvert fald et idéhistorisk perspektiv på 1000 års bemærkelsesværdig ekskluderende praksis, der har formet en social viden om romaerne som var de sigøjnere, altså indbegrebet af den negative idé om dem.

Sara Maria Sörensson

Historiske perspektiver på videnskab og religion

Casper Andersen \& Anders Munk Jensen: Videnskab og religion $i$ historisk perspektiv. Naturens fortolkere.
"Med en mæt slanges stædige dvaskhed afslår de at se i min kikkert. Den slags folk mener, at man ikke bør søge sandheden i naturen, men ved sammenligning af gamle tekster." Med disse ord stiger vi ind i det problemfelt, som en ny undervisningsbog om forholdet mellem religion og videnskab set $i$ et historisk perspektiv, tager under behandling. Citatet stammer fra den berømte naturforsker Galileo Galilei (1564-1642) og anslår bogens centrale anliggende: Det ofte konfliktfyldte forhold mellem en hhv. religiøs og en videnskabelig fortolkning af naturen. Forfatterne nærer en (berettiget) mistanke til, at den gængse modstilling mellem religion og videnskab er "mere velkendt end velbegrundet" (s.7), og deres forehavende er derfor at vise, at forholdet mellem religion og videnskab er langt mere komplekst og uselvfølgeligt end man - dvs. populærkulturen og de sensationshungrende medier - gerne efterlader indtryk af. Forfatternes modgift mod en sådan hensynsløs banalisering af problemstillingen består $i$ ordineringen af en øget sans for det historiske, i at "tage historien alvorligt" (s.97). Afgørende er, hævder forfatterne således, at nå til indsigt $i$, at hverken religion eller videnskab er uforanderlige størrelser, der svæver frit omkring $i$ et historisk vakuum. Såvel religion som videnskab er historisk og perspektivisk variable refleksionsprodukter, hvis indbyrdes relation derfor også ændrer sig igennem historien. 